\title{
Phosphorous Application Improves Drought Tolerance of Phoebe zhennan
}

\author{
Akash Tariq ${ }^{1,2}$, Kaiwen Pan ${ }^{1 *}$, Olusanya A. Olatunji',2, Corina Graciano ${ }^{3}$, Zilong Li', \\ Feng Sun ${ }^{1}$, Xiaoming Sun ${ }^{1}$, Dagang Song ${ }^{1}$, Wenkai Chen ${ }^{1}$, Aiping Zhang ${ }^{1}$, \\ Xiaogang $\mathrm{Wu}^{1}$, Lin Zhang ${ }^{1}$, Deng Mingrui ${ }^{1}$, Qinli Xiong ${ }^{1}$ and Chenggang Liu ${ }^{1,4}$
}

' CAS Key Laboratory of Mountain Ecological Restoration and Bioresource Utilization and Ecological Restoration Biodiversity Conservation Key Laboratory of Sichuan Province, Chengdu Institute of Biology, Chinese Academy of Sciences, Chengdu, China, ${ }^{2}$ International College, University of Chinese Academy of Sciences, Beijing, China, ${ }^{3}$ Instituto de Fisiología Vegetal, Consejo Nacional de Investigaciones Científicas y Técnicas - Universidad Nacional de La Plata, Buenos Aires, Argentina, ${ }^{4}$ Key Laboratory of Tropical Plant Resources and Sustainable Use, Xishuangbanna Tropical Botanical Garden, Chinese Academy of Sciences, Chengdu, China

Phoebe zhennan (Gold Phoebe) is a threatened tree species in China and a valuable and important source of wood and bioactive compounds used in medicine. Apart from anthropogenic disturbances, several biotic constraints currently restrict its growth and development. However, little attention has been given to building adaptive strategies for its conservation by examining its morphological and physio-biochemical responses to drought stress, and the role of fertilizers on these responses. A randomized experimental design was used to investigate the effects of two levels of irrigation (well-watered and drought-stressed) and phosphorous $(P)$ fertilization treatment (with and without $P$ ) to assess the morphological and physio-biochemical responses of $P$. zhennan seedlings to drought stress. In addition, we evaluated whether $\mathrm{P}$ application could mitigate the negative impacts of drought on plant growth and metabolism. Drought stress had a significant negative effect on the growth and metabolic processes of $P$. zhennan. Despite this, reduced leaf area, limited stomatal conductance, reduced transpiration rate, increased water use efficiency, enhanced antioxidant enzymes activities, and osmolytes accumulation suggested that the species has good adaptive strategies for tolerating drought stress. Application of $\mathrm{P}$ had a significant positive effect on root biomass, signifying its improved water extracting capacity from the soil. Moreover, $\mathrm{P}$ fertilization significantly increased leaf relative water content, net photosynthetic rate, and maximal quantum efficiency of PSII under drought stress conditions. This may be attributable to several factors, such as enhanced root biomass, decreased malondialdehyde content, and the up-regulation of chloroplast pigments, osmolytes, and nitrogenous compounds. However, P application had only a slight or negligible effect on the growth and metabolism of well-watered plants. In conclusion, P. zhennan has a strong capability for drought resistance, while $P$ application facilitates and improves drought tolerance mostly through physio-biochemical adjustments, regardless of water availability. It is imperative to explore the underlying metabolic mechanisms and effects of different levels of $P$ fertilization on $P$. zhennan under drought conditions in order to design appropriate conservation and management strategies for this species, which is at risk of extinction.

Keywords: Phoebe zhennan, drought stress, phosphorous fertilization, drought tolerance, conservation 


\section{INTRODUCTION}

Scenarios of climatic change predict an increase in the duration and severity of the drought events in major parts of the world, which will potentially affect nutrient availability, plant growth and productivity, and ecosystem function (Ledger et al., 2013; He and Dijkstra, 2014). The increased production of reactive oxygen species (ROS), as a result of drought stress, induces a series of morphological and metabolic changes that affect normal growth and development of many plant species (Keunen et al., 2013; Oliveira et al., 2014). Stress signals are first perceived at the membrane level by the receptors and then transduced in the cell to up-regulate stress response genes that facilitate stress tolerance (Mahajan and Tuteja, 2005). However, tolerance to environmental stress varies depending on plant species, growth stage and stress intensity (Demirevska et al., 2009).

Phosphorus $(\mathrm{P})$ is a key element required for normal plant development, but its low mobility in soil results in poor uptake by plants, which consequently inhibits growth and metabolism. The majority of soil types, including fertile soils, have low available $\mathrm{P}$, because the rate of absorption in the rhizosphere exceeds the rate of its replenishment in soil solution (Suriyagoda et al., 2011). Previous studies suggest that phosphorus contributes for the extension of root system and $\mathrm{P}$ deficiency will exacerbate drought stress (Cramer et al., 2009; Sardans and Penuelas, 2012). The use of P fertilizer reduces its deficiency in soil, increases the stress-tolerating ability of plants (Cortina et al., 2013) and results in adjustments of physiological, morphological, and biochemical processes that increase plant growth (dos Santos et al., 2004; Jones et al., 2005; Campbell and Sage, 2006; Faustino et al., 2013; Liu et al., 2015). Despite the importance of P in plant productivity, relatively few studies have assessed its effects on plant physiological and ecological processes under drought stress (dos Santos et al., 2006; Naeem and Khan, 2009; Fleisher et al., 2012; Jin et al., 2015; Liu et al., 2015). Most of these studies examined the relationship between $\mathrm{P}$ application and physiobiochemical adjustments under drought stress in non-woody plants (mostly crop species). Much less attention has been paid to evaluating the relationship between $\mathrm{P}$ application and drought resistance mechanisms in high quality, timber producing forest trees of conservation interest; this could be a potential area of research due to issues of possible future climate change.

Forest trees account for approximately $82 \%$ of terrestrial biomass and more than $50 \%$ of terrestrial biodiversity (Neale and Kremer, 2011), they help mitigate against climate change and provide a range of ecosystem services, such as nutrient cycling, carbon sequestration, water and air purification, and timber production for energy and industry (Harfouche et al., 2014). Globally, forest trees are increasingly subject to different types of environmental stresses that affect the growth and sustainability of trees. The predicted increase in global drought stress is likely to significantly impact forest trees by reducing nutrient supply and uptake and altering its redistribution in soils through mineralization (Schimel et al., 2007; Sanaullah et al., 2012). Studies on the effects of nutrient availability on the growth of woody species are common (He and Dijkstra, 2014), but there is little understanding about the possible role of nutrient application in the enhancement of stress tolerance ability of forest tree species.

The slow-growing, forest tree species, Phoebe zhennan S. Lee (Lauraceae; Golden Phoebe), is endemic to subtropical China and is widely distributed at elevations below $1,500 \mathrm{~m}$ (Hu et al., 2015). While P. zhennan is an economically important timber and medicinal species, it has been listed as a threatened species by International Union for Conservation of Nature (IUCN) and is nationally protected (Gao et al., 2016). Apart from anthropogenic disturbances, studies of forest plantations have suggested that P. zhennan rarely reaches its full growth potential due to abiotic constraints (Wu, 2009) such as drought stress. Although Hu et al. (2015) studied the antioxidative response of P. zhennan to drought conditions; this was a short-term study of 1 month duration and, as such, does not provide a detailed understanding of the effect of drought stress on growth and physio-biochemical impairment or adaptive strategies. Nevertheless, it has been suggested that slow-growing species are less sensitive to soil mineral and drought stress, because of their low mineral absorption rate and slow growth strategy (Chapin, 1980) and it is possible that $P$. zhennan may possess inherent strategies to abiotic stress. There is a lack of understanding of growth and metabolic responses by $P$. zhennan to drought stress and the possible associated morphological and physio-biochemical adaptive strategies. Moreover, to the best of our knowledge, there is no published research examining how $\mathrm{P}$ fertilizer application may help mitigate drought stress in $P$. zhennan. The likelihood of climate change mediated increases in arid conditions may have implications for the economically important, but threatened P. zhennan. Thus, research to promote the understanding of drought tolerance and response mechanisms to addition of $\mathrm{P}$ fertilizer in $P$. zhennan is timely.

In this study, we addressed the following objectives (1) to assess the morphological and physio-biochemical responses of $P$. zhennan to drought stress; and (2) to evaluate whether $P$ application mitigates the negative impact of drought by improving the tolerance capacity of P. zhennan. Accordingly, we investigated plant growth, water status, gas exchange, chlorophyll fluorescence, reactive oxygen production rate, antioxidant enzyme activities, and biochemical parameters.

\section{MATERIALS AND METHODS}

\section{Experiment Design}

The experiment was conducted at the Center for Ecological Studies at the Chinese Academy of Sciences, Sichuan in southwest China. Healthy and uniform, 2-year-old P. zhennan plants were collected from Sichuan Agricultural University, Sichuan province, and transplanted to $10 \mathrm{~L}$ plastic pots filled with approximately $4 \mathrm{~kg}$ of homogenized topsoil $(\mathrm{pH} 7.3$, total nitrogen $0.19 \%$, and carbon $2.67 \%$ ). The pots were arranged in a complete randomized block design in a greenhouse (temperature range $18-32^{\circ} \mathrm{C}$, relative humidity range $50-85 \%$ ) and regularly watered. Light availability was homogeneous inside the greenhouse, and direct sunlight reduction due to covering was in the range of $6-9 \%$. After growing for 2 months in the 
greenhouse, the plants were subject to three replicates of four treatments for 90 days: two water regimes (well-watered and water-stressed) and two levels of $\mathrm{P}$ fertilization (with and without $\mathrm{P}$ fertilization). Immediately prior to applying the treatments, total and available $\mathrm{P}$ in soils was first determined to be $0.89 \mathrm{~g}$ $\mathrm{kg}^{-1}$ and $27.6 \mathrm{mg} \mathrm{kg}^{-1}$, respectively. Available $\mathrm{P}$ was extracted with $0.5 \mathrm{M} \mathrm{NaHCO}_{3}$ (pH 8.2) according to Olsen and Sommers (1982) and measured colorimetrically by the molybdate-ascorbic acid as described by Murphy and Riley (1962). Soil relative water content (SRWC) of the two water treatments (control: $80-85 \%$; severe drought: 30-35\%) was calculated using the weight method (Xu et al., 2009). The pots were weighed daily and watered up to their respective target SRWC, by replacing the amount of water transpired and evaporated. SRWC was expressed as:

$$
\mathrm{SRWC}=\left(W_{\text {soil }}+W_{\text {pot }}+D W_{\text {soil }}\right) /\left(W_{\mathrm{FC}}-W_{\text {pot }}\right)
$$

where $W_{\text {soil }}$ was the current soil weight, $W_{\text {pot }}$ was the weight of the empty pot, $D W_{\text {soil }}$ was the dry soil weight, and $W_{\mathrm{FC}}$ was the soil weight at field capacity.

Phosphorous fertilization was supplied as sodium dihydrogen phosphate $\left(\mathrm{NaH}_{2} \mathrm{PO}_{4}, 25.5 \% \mathrm{P}\right)$ with the dose of $129.3 \mathrm{mg} \mathrm{P}$ mixed in $200 \mathrm{~mL}$ water per pot every 30 days. In order to avoid systematic error produced by fluctuation in environmental conditions, pots were rotated after every 5 days during the experiment. Each treatment was replicated three times. Plant samples were collected at the end of the experiment.

\section{Plant Growth and Biomass}

Plant height $(\mathrm{cm})$, stem diameter $(\mathrm{mm})$, and leaf area $\left(\mathrm{cm}^{2}\right)$ were measured by using a measuring tape, caliper, and a leaf area meter (CI 202, United States), respectively. After removing the plants from the soil, roots, stems, and leaves were separated and weighed. Samples were oven dried at $70^{\circ} \mathrm{C}$ for $24 \mathrm{~h}$, to measure biomass.

\section{Leaf Relative Water Content}

Expanded leaves were collected from each plant and weighed to obtain fresh weight (FW). The leaves were then immediately dipped into distilled water at a temperature of $4^{\circ} \mathrm{C}$ and under dark conditions. After $12 \mathrm{~h}$, leaves were weighed to obtain turgor weight (TW) and then dried for $24 \mathrm{~h}$ in an oven set at $70^{\circ} \mathrm{C}$ to determine dry weight (DW). The following equation was used to calculate leaves relative water content (LRWC).

$$
\mathrm{LRWC}=[(\mathrm{FW}-\mathrm{DW}) /(\mathrm{TW}-\mathrm{DW})] \times 100 \% .
$$

\section{Gas Exchange and Chlorophyll Fluorescence}

The net $\mathrm{CO}_{2}$ assimilation rate $\left(P_{\mathrm{n}}\right)$, stomatal conductance $\left(G_{\mathrm{s}}\right)$, and intercellular $\mathrm{CO}_{2}$ concentration $\left(C_{\mathrm{i}}\right)$ were measured with a portable open-flow gas exchange system (LI-6400, LI-COR Inc., United States), between 9:00 and 11:00 h, on fully expanded leaves that were at similar stages of development. During this time, relative air humidity, $\mathrm{CO}_{2}$ concentration, and photon flux density were maintained at $60-70 \%, 380 \mu \mathrm{mol} \mathrm{mol}{ }^{-1}$ and $800 \mu \mathrm{mol}$ $\mathrm{m}^{-2} \mathrm{~s}^{-1}$, respectively. Intrinsic water use efficiency (WUE $\mathrm{intr}_{\text {) }}$ was calculated by dividing the instantaneous values of $P_{\mathrm{n}}$ by $G_{\mathrm{s}}$. The maximum quantum efficiency of photosystem II $\left(F_{\mathrm{v}} / F_{\mathrm{m}}\right)$ of the leaves was measured with a portable pulse amplitude modulated fluorometer (PAM-2100, Walz, Effeltrich, Germany), where the leaves were dark-adapted with clips for $20 \mathrm{~min}$. After this time, minimal fluorescence $\left(F_{\mathrm{o}}\right)$ was measured under a weak pulse of modulating light over $0.8 \mathrm{~s}$, and maximal fluorescence $\left(F_{\mathrm{m}}\right)$ was induced by a saturating pulse of light $(8,000 \mathrm{mmol}$ $\left.\mathrm{m}^{-2} \mathrm{~s}^{-1}\right)$ applied over $0.8 \mathrm{~s} . F_{\mathrm{v}} / F_{\mathrm{m}}$ was calculated, where $F_{\mathrm{v}}$ was the difference between $F_{\mathrm{m}}$ and $F_{\mathrm{o}}$.

\section{Photosynthetic Pigments}

Chlorophyll $a(\mathrm{Chl} a)$, chlorophyll $b(\mathrm{Chl} b)$, and carotenoids (Car) were determined using 0.2 g FW leaf samples, with $80 \%$ acetone as a solvent. Leaf samples were placed in dark conditions for $36 \mathrm{~h}$ and absorbance was recorded at 662, 645, and $470 \mathrm{~nm}$ spectrophotometrically (Lichtenthaler and Buschmann, 2001).

\section{Determination of Biochemical Parameters}

Dried leaf samples $(0.2 \mathrm{~g} \mathrm{DW})$ were mixed with $6 \mathrm{~mL}$ of $80 \%$ ethanol at $80^{\circ} \mathrm{C}$ for $30 \mathrm{~min}$. The resulting extracted supernatant was analyzed for soluble sugars (SS) following the anthrone method using sucrose as a standard (Zhang and Qu, 2003). For $\mathrm{NO}_{3}{ }^{-}$concentration, $0.2 \mathrm{~g}$ of frozen leaves was homogenized in $5 \mathrm{~mL}$ of deionized water, while for $\mathrm{NH}_{4}{ }^{+}$concentration, $0.2 \mathrm{~g}$ of frozen leaves was homogenized in $2 \mathrm{~mL}$ of $10 \% \mathrm{HCl}$. The resulting supernatants were analyzed using a quantitative colorimetric method as described by Tang (1999). Proline was extracted with $2 \mathrm{~mL}$ of $10 \%$ acetic acid and $5 \mathrm{~mL}$ of $3 \%$ sulfosalicylic acid, respectively. The resulting supernatants were analyzed according to the method of Liu et al. (2014). Soluble proteins (SP) were determined using Bradford G-250 reagent.

\section{ROS and Lipid Peroxidation}

Two measures of ROS were estimated. Firstly, production rate of superoxide anion $\left(\mathrm{O}_{2}{ }^{-}\right)$was measured by monitoring nitrite formation from hydroxylamine, in the presence of $\mathrm{O}_{2}{ }^{--}$(Elstner and Heupel, 1976). Fresh leaves (0.2 g) were homogenized with $2 \mathrm{~mL}$ of $65 \mathrm{mM}$ phosphate buffer ( $\mathrm{pH} 7.8$ ) and centrifuged at $5000 \times g$ for $10 \mathrm{~min}$. The incubation mixture contained $0.9 \mathrm{~mL}$ of $65 \mathrm{mM}$ phosphate buffer ( $\mathrm{pH} 7.8), 0.1 \mathrm{~mL}$ of $10 \mathrm{mM}$ hydroxylammonium chloride, and $1 \mathrm{~mL}$ of supernatant. After incubation at $25^{\circ} \mathrm{C}$ for $20 \mathrm{~min}, 17 \mathrm{mM}$ sulphanilamide, and $7 \mathrm{mM}$ $\alpha$-naphthylamine were added to the incubation mixture and kept at $25^{\circ} \mathrm{C}$ for $20 \mathrm{~min}$. Ethyl ether in the same volume was added and centrifuged at $1500 \times g$ for $5 \mathrm{~min}$. The absorbance wavelength for the aqueous solution was $530 \mathrm{~nm}$.

Secondly, hydrogen peroxide $\left(\mathrm{H}_{2} \mathrm{O}_{2}\right)$ concentration was determined by monitoring the absorbance of the titaniumperoxide complex at $410 \mathrm{~nm}$ (Patterson et al., 1984). Fresh leaves $(0.2 \mathrm{~g})$ were homogenized with $5 \mathrm{~mL}$ of acetone and centrifuged at $3,000 \times g$ for $10 \mathrm{~min}$. The reactive mixture, containing $0.1 \mathrm{~mL}$ of titanium reagent $(50 \mu \mathrm{L}$ of $20 \%$ titanium tetrachloride in concentrated $\mathrm{HCl}$ ), $0.2 \mathrm{~mL}$ of ammonia, and $1 \mathrm{~mL}$ of supernatant, was centrifuged at $3,000 \times g$ for $10 \mathrm{~min}$. The resulting precipitate 
was washed five times with acetone, before being centrifuged at $10,000 \times g$ for $5 \mathrm{~min}$. The precipitate was solubilized in $3 \mathrm{~mL}$ of $1 \mathrm{M} \mathrm{H}_{2} \mathrm{SO}_{4}$ and the absorbance at $410 \mathrm{~nm}$ was measured. Lipid peroxidation was estimated by measuring malondialdehyde (MDA) content according to the thiobarbituric acid (TBA) test at 450, 532, and $600 \mathrm{~nm}$, respectively (Zhou et al., 2007). For MDA assay, $0.25 \mathrm{~g}$ of fresh leaves were ground in $5 \mathrm{~mL}$ of $1 \%$ trichloroacetic acid (TCA) and centrifuged at 5,000 $\mathrm{g}$ for 10 min. Supernatant $(1 \mathrm{~mL})$ was added to $4 \mathrm{~mL}$ of $20 \%$ TCA (containing $0.5 \% \mathrm{TBA}$ ) and the mixture was heated at $95^{\circ} \mathrm{C}$ for $30 \mathrm{~min}$, before being cooled in an ice bath. Absorbance was read using a spectrophotometer at 450, 532, and $600 \mathrm{~nm}$ (Zhou et al., 2007). The MDA concentration was calculated using the following equation:

$$
\operatorname{MDA}\left(\mathrm{molg}^{-1} \mathrm{FW}\right)=6.45(\mathrm{OD} 532-\mathrm{OD} 600)-0.56 \mathrm{OD} 450
$$

\section{Antioxidant Enzyme Activities}

Three measures of antioxidant stress were assessed. Superoxide dismutase (SOD) activity was determined using the nitroblue tetrazolium (NBT) method (Fu and Huang, 2001). One unit of SOD activity was defined as the amount of enzyme required for $50 \%$ inhibition of NBT reduction at $560 \mathrm{~nm}$. Activities of catalase (CAT) and peroxidase (POD) were determined using the methods of Fu and Huang (2001). For CAT, the decomposition of $\mathrm{H}_{2} \mathrm{O}_{2}$ was determined by measuring the reduction in absorbance at $240 \mathrm{~nm}$ for $1 \mathrm{~min}$. For POD, the oxidation of guaiacol was determined by measuring the increase in absorbance at $470 \mathrm{~nm}$ for $1 \mathrm{~min}$. One unit of CAT and POD activity was defined as an absorbance change of 0.01 unit's $\min ^{-1}$.

\section{Statistical Analysis}

All measurements were repeated three times, and the data were organized using Microsoft Excel 2007 and presented as means \pm standard errors (SEs). SPSS version 16.0 (Chicago, IL, United States) was used to run one-way analysis of variance (ANOVA) and Duncan's multiple range tests at the 0.05 significance probability level were used to compare mean values. Prior to analysis, data were checked for normality and homogeneity of variances. Origin pro 8.5 was used for graphical presentation; error bars represent standard errors, and all data in the figures represent the means \pm SEs.

\section{RESULTS}

\section{Plant Growth and Biomass}

Reduction in morphological traits was observed in droughtstressed plants compared with well-watered plants (Table 1). Under water deficit conditions, shoots and root biomass, leaf area and stem diameter significantly decreased (45.2, 39.8, 28.5 , and $9.1 \%$, respectively) compared with well-watered plants irrespective of $\mathrm{P}$ application. Root biomass in drought-stressed plants was significantly higher $(14.4 \%)$ in fertilized plants than in unfertilized plants. There were no significant treatment differences for the other growth parameters.

\section{Leaf Relative Water Content, Photosynthetic and Chlorophyll Fluorescence}

In comparison with well-watered unfertilized plants there was a significant reduction in LRWC, $P_{\mathrm{n}}, F_{\mathrm{v}} / F_{\mathrm{m}}, C_{\mathrm{i}}$, and $G_{\mathrm{s}}(27.2,72.6,17.2,34.72$, and $73.94 \%$, respectively) of drought-stressed unfertilized plants. Under drought stress conditions, LRWC, $P_{\mathrm{n}}$, and $F_{\mathrm{v} /} F_{\mathrm{m}}$ were significantly lower in unfertilized plants than in fertilized plants, while there were no significant effects of fertilizer on the other parameters in drought-stressed plants (Table 2). Water use efficiency (WUE $E_{\text {intr }}$ ) showed an opposite trend and increased $44.13 \%$ under drought condition than well-watered plants, regardless of $\mathrm{P}$ application. However, there was no significant change in $\mathrm{WUE}_{\text {intr }}$ in $\mathrm{P}$ fertilized plants under water-stressed conditions. There was no effect of $\mathrm{P}$ fertilizer on LRWC or any of the photosynthetic and chlorophyll parameters in wellwatered plants. Moreover, under drought condition water consumption rate was higher in P-fertilized plants than unfertilized plants but lower than well-watered plants (data not shown).

\section{Photosynthetic Pigments}

Concentration of Chl $a$ and Chl $b$ in non-fertilized plants was significantly lower (22.2 and $40.0 \%$, respectively) in waterstressed than in well-watered plants (Figures 1A,B). We found that $\mathrm{Chl} a$ and $\mathrm{Chl} b$ concentration was significantly greater in drought-stressed plants that had been treated with fertilizer than in those that had been unfertilized. Neither water nor

TABLE 1 | Changes in morphological parameters of Phoebe zhennan for non-fertilized $(-P)$ and fertilized $(+P)$ treatments with and without water stress.

\begin{tabular}{|c|c|c|c|c|}
\hline \multirow[t]{2}{*}{ Traits } & \multicolumn{2}{|c|}{ Well-watered } & \multicolumn{2}{|c|}{ Water-stressed } \\
\hline & $-P$ & $+\mathbf{P}$ & $-\mathbf{P}$ & $+P$ \\
\hline Leaf biomass (g) & $2.12 \pm 0.29 a$ & $1.98 \pm 0.48 a$ & $1.52 \pm 0.08 a$ & $1.55 \pm 0.06 a$ \\
\hline Shoot biomass (g) & $9.99 \pm 0.9 a$ & $9.7 \pm 0.87 a$ & $5.47 \pm 0.42 b$ & $5.96 \pm 0.45 b$ \\
\hline Root biomass (g) & $5.18 \pm 0.17 a$ & $5.37 \pm 0.12 a$ & $3.12 \pm 0.08 c$ & $3.57 \pm 0.12 b$ \\
\hline Leaf area $\left(\mathrm{cm}^{2}\right)$ & $32.55 \pm 3.03 a$ & $32.72 \pm 1.73 a$ & $23.26 \pm 1.1 b$ & $22.19 \pm 0.71 b$ \\
\hline Height $(\mathrm{cm})$ & $34.33 \pm 1.2 \mathrm{a}$ & $35.33 \pm 2.19 a$ & $32.33 \pm 1.2 \mathrm{a}$ & $33.33 \pm 0.88 a$ \\
\hline Diameter (mm) & $4.81 \pm 0.1 a$ & $4.68 \pm 0.11 a b$ & $4.37 \pm 0.09 b$ & $4.47 \pm 0.13 a b$ \\
\hline
\end{tabular}

Means followed by different letters indicate significant differences $(P \leq 0.05)$ among the four treatments according to Duncan's test. Values are means \pm SE. 
fertilizer treatment had any effect on carotenoid concentration (Figure 1C).

\section{Biochemical Parameters}

The concentration of $\mathrm{NH}_{4}{ }^{+}$was higher in well-watered plants than drought-stressed plants, while the opposite was found for proline concentration (Table 3). With the exception of SS concentration, which was greater in fertilized than unfertilized drought-stressed plants, we found no significant effect on biochemical parameters of fertilizer within well-watered or drought-stressed plants.

\section{ROS Production and Lipid Peroxidation}

Regardless of $\mathrm{P}$ application, measures of ROS production $\left(\mathrm{O}_{2}-\right.$ and $\mathrm{H}_{2} \mathrm{O}_{2}$ ) and lipid peroxidation (MDA) were significantly higher in plants under drought stress conditions than in wellwatered plants (Figure 2). Addition of $\mathrm{P}$ had no significant effect on concentration of either both $\mathrm{O}_{2}-$ and $\mathrm{H}_{2} \mathrm{O}_{2}$ in the two water treatments or MDA in well-watered plants; however, it resulted in significantly lower MDA content in drought-stressed plants (Figures 2A-C).

\section{Antioxidant Stress}

Activity of POD and CAT was higher in drought-stressed plants than in well-watered plants, and SOD activity was highest in unfertilized, drought stress plants (Figure 3). Addition of P had no significant effect on the measures of antioxidant stress in either of the water treatments.

\section{DISCUSSION}

\section{Drought Stress and Biomass}

Drought stress is considered a major environmental stress that adversely affects tree growth and forest productivity around the world (Bartlett et al., 2012; Harfouche et al., 2014). We found that, irrespective of $\mathrm{P}$ application, biomass of the above and below ground plant parts of $P$. zhennan was significantly lower under drought stress conditions compared with wellwatered conditions. Low water content in soil decreases mobility of available ions, nutrient availability, and microbial activities in the soil (Hu and Schmidhalter, 2001). Furthermore, root interaction with arbuscular mycorrhizas (AM) can increase plant tolerance to drought because the fungi improves plant water status by modulating ABA-mediated abiotic signaling pathway involving D-myo-inositol-3-phosphate synthase (IPS) and 143-3 proteins ( $\mathrm{Li}$ et al., 2016). Moreover, in the plant it causes partial or total stomatal closure, drop in water potential, loss of cell turgor reduction of cell expansion, and if the dehydration is severe, the disruption of normal bilayer structure of the cell membranes through a reduction in synthesis, and possibly denaturation of cytosolic and organelle protein that leads to impaired cell metabolism (Mahajan and Tuteja, 2005). We found that application of $\mathrm{P}$ to plants under drought stress resulted in significantly greater root biomass, which may be attributed to several factors, including increased uptake of $\mathrm{P}$, higher consumption rate of assimilates in root material, and enhanced hydraulic conductance of the root system (Garg et al., 2004). Phosphorous application plays an important role in root development thereby increasing accessibility to other nutrients in the rhizosphere (Liao and Yan, 2000; Razaq et al., 2017). Moreover, the root tip is responsible for sensing and signaling of $\mathrm{P}$ availability, and to initialize the reduction in root growth in $\mathrm{P}$ deficient environments and the proteins containing an SPX domain are important in regulating not only P uptake but also P distribution within subcellular compartments (Rouached et al., 2010). Higher root biomass also improves the ability of roots to extract soil moisture, contributing to drought tolerance (Meng and Yao, 2015); therefore, P application may enhance the drought tolerance of $P$. zhennan through the promotion of root biomass. This higher root biomass would be a further advantage in drought conditions where water is available in deeper soil profiles (Tardieu, 2012). We also found that P fertilization had no effect on the biomass of above and below ground plant parts in well-watered condition and suggest this may be due to the slow-growing nature of $P$. zhennan, and/or the sufficient availability of $\mathrm{P}$ in the soil to meet the functional requirements of the establishing seedlings. Curiously, our results contrast with studies that report increased growth rate and biomass accumulation in P fertilized plants (Graciano et al., 2005; Jones et al., 2005; Ram et al., 2006) but support other studies that suggest non-significant effects of $\mathrm{P}$ fertilization on

TABLE 2 | Changes in leaf relative water content, photosynthetic and chlorophyll fluorescence parameters, water use efficiency in $P$. zhennan for non-fertilized (-P) and fertilized $(+P)$ treatments with and without water stress.

\begin{tabular}{|c|c|c|c|c|}
\hline \multirow[t]{2}{*}{ Traits } & \multicolumn{2}{|c|}{ Well-watered } & \multicolumn{2}{|c|}{ Water-stressed } \\
\hline & $-\mathbf{P}$ & $+\mathbf{P}$ & $-\mathbf{P}$ & $+\mathbf{P}$ \\
\hline LRWC (\%) & $41.5 \pm 1.93 a$ & $41.7 \pm 2.74 a$ & $30.2 \pm 0.89 b$ & $36.3 \pm 1.16 a$ \\
\hline$P_{\mathrm{n}}\left(\mu \mathrm{mol} \mathrm{m} \mathrm{m}^{-2} \mathrm{~s}^{-1}\right)$ & $2.57 \pm 0.11 a b$ & $3.11 \pm 0.3 a$ & $1.24 \pm 0.07 c$ & $2.03 \pm 0.29 b$ \\
\hline$C_{\mathrm{i}}\left(\mu \mathrm{mol} \mathrm{mol}{ }^{-1}\right)$ & $248.21 \pm 17.16 a$ & $249.91 \pm 15.8 \mathrm{a}$ & $162.02 \pm 10.8 b$ & $207.88 \pm 16.39 a b$ \\
\hline$G_{s}\left(m o l m^{-2} s^{-1}\right)$ & $0.036 \pm 0.004 a b$ & $0.047 \pm 0.0136 a$ & $0.0093 \pm 0.0003 c$ & $0.0209 \pm 0.0049 b c$ \\
\hline WUE $E_{\text {intr }}\left(\mu \mathrm{mol} \mathrm{mol}{ }^{-1}\right)$ & $74.4 \pm 11.73 b$ & $73.17 \pm 12.53 b$ & $133.18 \pm 7.17 \mathrm{a}$ & $101.51 \pm 11.16 \mathrm{ab}$ \\
\hline$E\left(\mathrm{mmol} \mathrm{m} \mathrm{m}^{-2} \mathrm{~s}^{-1}\right)$ & $1.51 \pm 0.18 \mathrm{ab}$ & $1.86 \pm 0.62 a$ & $0.4 \pm 0.01 b$ & $0.89 \pm 0.17 a b$ \\
\hline$F_{\mathrm{v}} / F_{\mathrm{m}}$ & $0.81 \pm 0.02 a$ & $0.82 \pm 0.02 a$ & $0.67 \pm 0.01 c$ & $0.74 \pm 0.02 b$ \\
\hline
\end{tabular}

Means followed by different letters indicate significant differences $(P \leq 0.05)$ among the four treatments according to Duncan's test. Values are means \pm SE. 


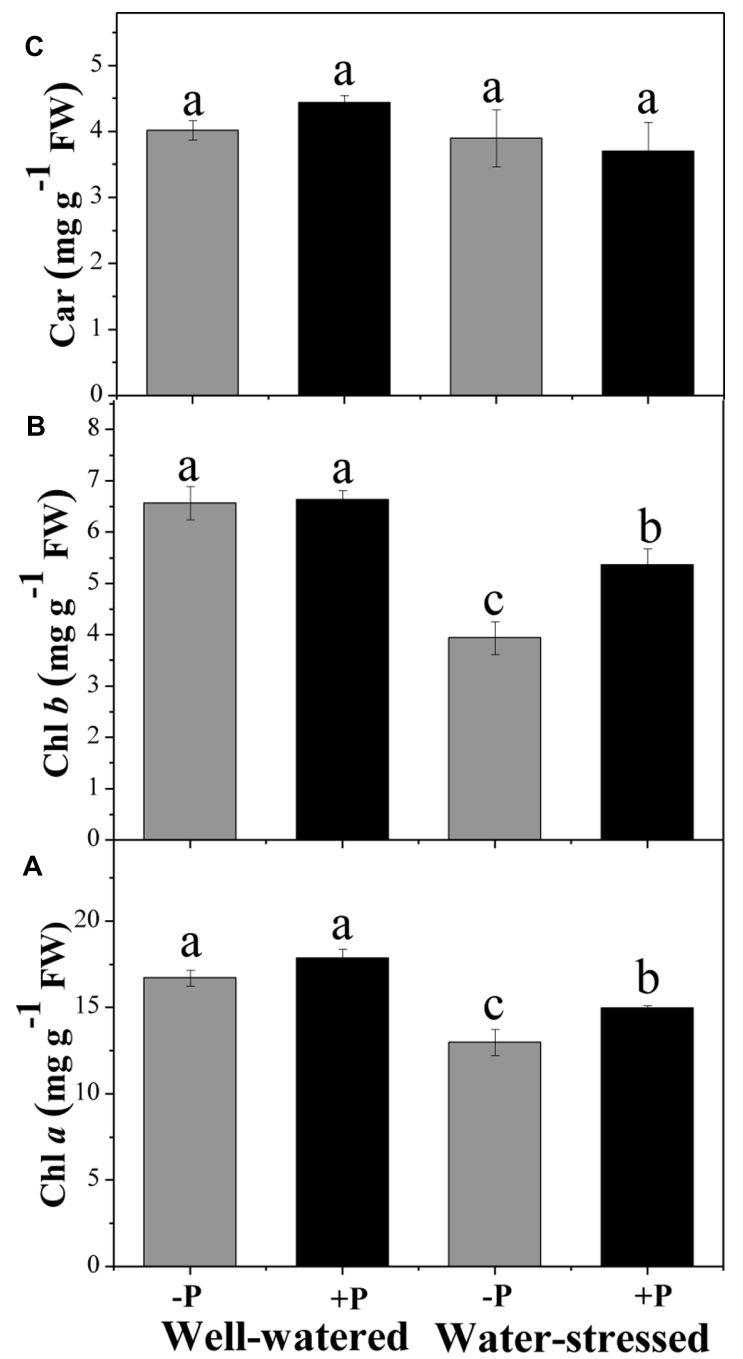

FIGURE 1 | Changes in chloroplast pigments, chlorophyll a (Chl a, A), chlorophyll b $(\mathrm{Chl} b, \mathbf{B})$, and carotenoids $(\mathrm{Car}, \mathbf{C})$ for fertilized $(+\mathrm{P})$ and non-fertilized $(-P)$ treatments with and without water. Means followed by different letters indicate significant differences $(P \leq 0.05)$ among the four treatments according to Duncan's test. Vertical bars show $\pm \mathrm{SE}$.

growth parameters (Yin et al., 2012; Liu et al., 2015). The high variability in the responses of different plant species to $\mathrm{P}$ application may be because response to fertilization depend on the species, available nutrients, nutrient interactions, soil physical properties, water availability, among many other factors that modulate the response of the plant to an increase in particular nutrient concentration in the soil. Absorption of $\mathrm{P}$ takes place at the soil surface, and its lower diffusion rate and slower movement toward the root, compared with other nutrients, possibly affect its use efficiency (Schachtman et al., 1998; Grant et al., 2005). However, in greenhouse experiments, growing conditions are well controlled; therefore P use efficiency can be improved if $\mathrm{P}$ is mixed uniformly with the volume exploited by roots (Mitchell, 1957; Sample et al., 1980). However, P use efficiency varied within a species. For example in Hordeum vulgare the expression of the gene HVPT5, that can be used to estimate phosphate use efficiency, was higher under low $\mathrm{P}$ availability in a tolerant accession, but its expression did not change in the sensitive accession (Ren et al., 2016). Moreover, plants have inducible high affinity phosphate transporters and constitutive low affinity phosphate transporters encoded by Pht (phosphate transporter) gene family that ensure $\mathrm{P}$ uptake from the soil and distribution within different organelles of plant to sustain photosynthesis, respiration, and growth even under low P availability conditions (López-Arredondo et al., 2014). Member of Pht1 gene family encoded high affinity P transporters which are mostly expressed in epidermal and outer cortex of the root cells and have already been identified as mediators of P uptake when P is limited (Schunmann et al., 2004). However, members of the Pht2, Pht3, and Pht4 gene families were found to be associated mostly with $\mathrm{P}$ distribution within subcellular compartments (Versaw and Harrison, 2002; Guo et al., 2008). Moreover, recently, the role of microRNAs (miRNAs) has been revealed in the regulation of $\mathrm{P}$ homeostasis (Doerner, 2008). miRNA399 has been uncovered as a component of the shootto-root $\mathrm{P}$ deficiency signaling pathway, it moves via phloem and repress E2-conjugase which causes increase in the expression of root $\mathrm{P}$ uptake transporters and hence in the acquisition of $\mathrm{P}$ by the roots and its translocation and distribution to the shoot (Lin et al., 2008).

We found that leaf area of drought-stressed plants was significantly lower than in well-watered plants, irrespective of $\mathrm{P}$ application. Generally, water deficiency during the vegetative growth stage changes leaf turgidity and temperature, and reduces the supply of assimilates, thus inhibiting leaf growth. In drought tolerant plant species, reduction in leaf area is considered an adaptive strategy to reduce water loss through transpiration (Rostamza et al., 2011). However, the lack of difference in leaf area, but higher $P n$ rate and LRWC that we observed in $\mathrm{P}$ fertilized, drought-stressed $P$. zhennan, suggests better acclimatory response to drought stress conditions. Dehydration tolerance of a plant can be measured using the LRWC index. In our study, LRWC in plants under drought conditions was significantly lower than that in well-watered plants. Reductions in LRWC in response to drought-stressed conditions have also been observed in different plant species (Shubhra et al., 2004; Yang and Miao, 2010). We found that P fertilizer increased LRWC in drought-stressed plants, but not in well-watered plants. The higher LRWC in fertilized, drought-stressed plants in our study may be associated with the greater biomass of $\mathrm{P}$ fertilized plants. Several studies have also reported improved LRWC due to either an improved ability of root to extract water or an improved conservation of water in the plant tissues (Centritto et al., 1999; Garg et al., 2004; Shubhra et al., 2004; Sato et al., 2010). However, our results contradict several studies that showed non-significant effects of P fertilization on LRWC under water deficit condition (dos Santos et al., 2004; Singh et al., 2006; Liu et al., 2015). This variability in the effect of $\mathrm{P}$ in drought-stressed plant species may be due to interspecific differences in physiological, biochemical, and molecular mechanisms, such as gene expression and protein assimilation. Genes induced by drought stress have been shown to not only protect plant cells from dehydration but also regulate 
TABLE 3 | Osmolytes accumulation (soluble sugars concentration) and concentration of nitrogenous compounds reduction and assimilation in $P$. zhennan for non-fertilized $(-P)$ and fertilized $(+P)$ treatments with and without water stress.

\begin{tabular}{|c|c|c|c|c|}
\hline \multirow[t]{2}{*}{ Traits } & \multicolumn{2}{|c|}{ Well-watered } & \multicolumn{2}{|c|}{ Water-stressed } \\
\hline & $-\mathbf{P}$ & $+\mathbf{P}$ & $-\mathbf{P}$ & $+\mathbf{P}$ \\
\hline Soluble sugars $\left(\mathrm{mg} \mathrm{g}^{-1} \mathrm{DW}\right)$ & $0.44 \pm 0.01 b$ & $0.41 \pm 0.02 b$ & $0.47 \pm 0.02 b$ & $0.57 \pm 0.03 a$ \\
\hline $\mathrm{NH}_{4}+\left(\mathrm{mg} \mathrm{g}^{-1} \mathrm{DW}\right)$ & $0.93 \pm 0.03 a$ & $0.93 \pm 0.06 a$ & $0.63 \pm 0.04 b$ & $0.77 \pm 0.058 \mathrm{~b}$ \\
\hline $\mathrm{NO}_{3}-\left(\mathrm{mg} \mathrm{g}^{-1} \mathrm{DW}\right)$ & $2.75 \pm 0.2 \mathrm{a}$ & $2.85 \pm 0.1 \mathrm{a}$ & $2.01 \pm 0.16 b$ & $2.33 \pm 0.12 a b$ \\
\hline Soluble proteins $\left(\mathrm{mg} \mathrm{g}^{-1} \mathrm{DW}\right)$ & $65.33 \pm 4.03 \mathrm{ab}$ & $67.55 \pm 1.6 \mathrm{a}$ & $57.94 \pm 0.9 b$ & $60.1 \pm 1.41 \mathrm{ab}$ \\
\hline Proline $\left(\mathrm{mg} \mathrm{g}^{-1} \mathrm{DW}\right)$ & $0.037 \pm 0.001 b$ & $0.036 \pm 0.003 b$ & $0.055 \pm 0.006 a$ & $0.057 \pm 0.004 a$ \\
\hline
\end{tabular}

Means followed by different letters indicate significant differences $(P \leq 0.05)$ among the four treatments according to Duncan's test. Values are means \pm SE.

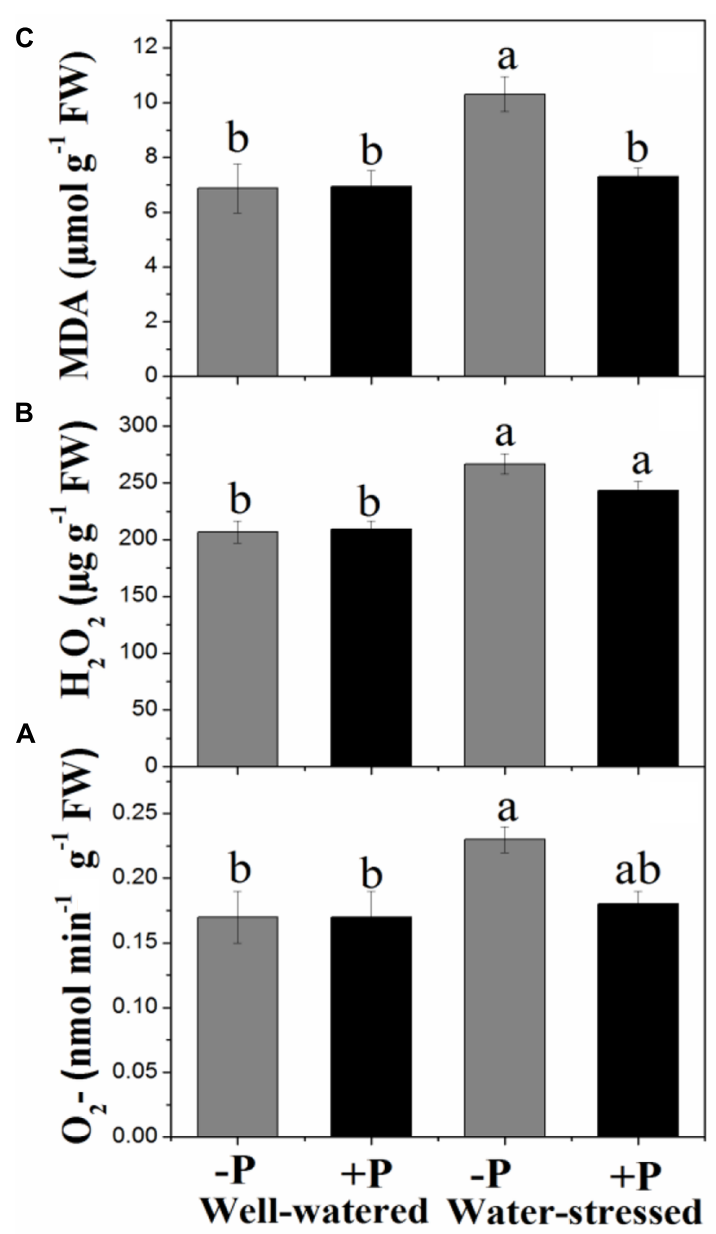

FIGURE 2 | Changes in superoxide anion $\left(\mathrm{O}_{2} \cdot{ }^{-}, \mathbf{A}\right)$, hydrogen peroxide $\left(\mathrm{H}_{2} \mathrm{O}_{2}, \mathbf{B}\right)$, and lipid peroxidation (MDA, C) for fertilized $(+\mathrm{P})$ and non-fertilized $(-P)$ treatments with and without water. Means followed by different letters indicate significant differences $(P \leq 0.05)$ among the four treatments according to Duncan's test. Vertical bars show \pm SE.

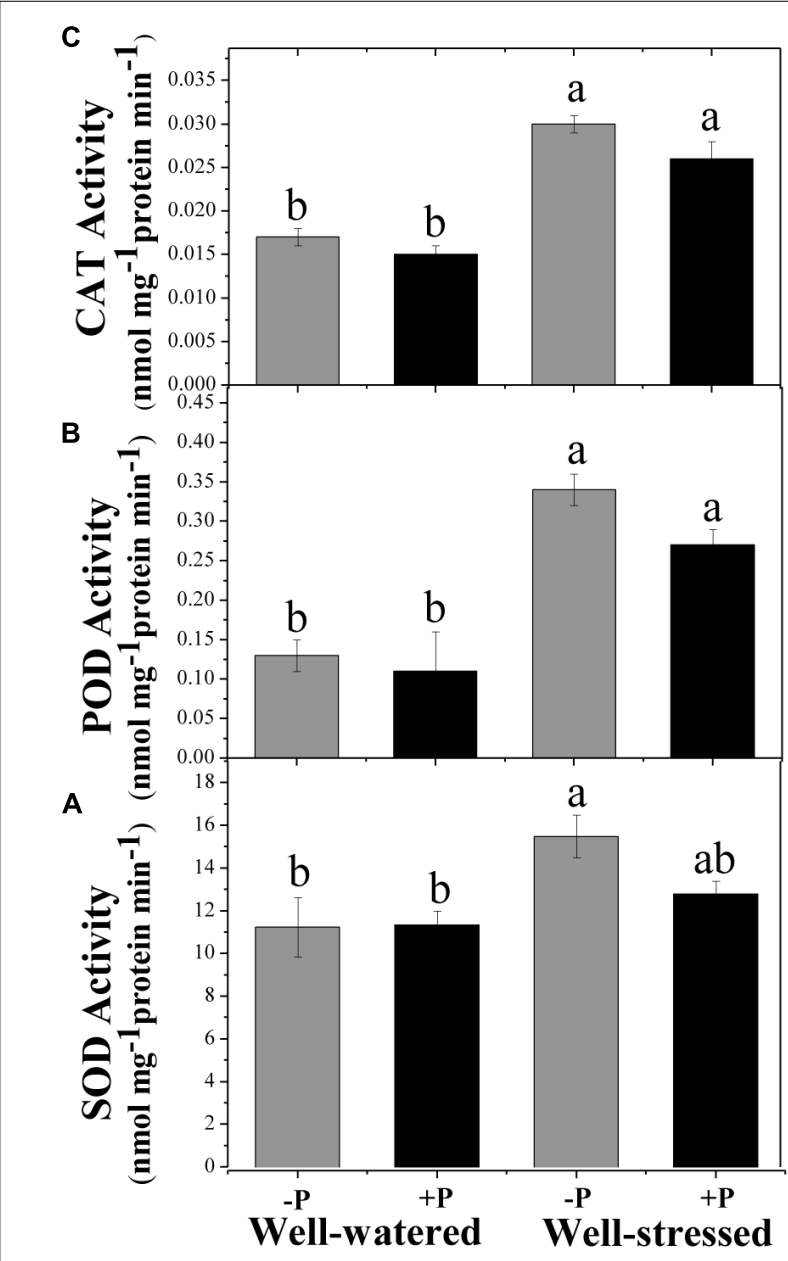

FIGURE 3 | Changes in superoxide dismutase (SOD, A), peroxidase (POD, B), and catalase (CAT, C) for fertilized $(+P)$ and non-fertilized $(-P)$ treatments with and without water. Means followed by different letters indicate significant differences $(P \leq 0.05)$ among the four treatments according to Duncan's test. Vertical bars show $\pm \mathrm{SE}$.

and $\mathrm{N}$ availability in plant water use was demonstrated in the subtropical trees Eucalyptus grandis and Pinus taeda (Faustino et al., 2013; Graciano et al., 2016; Costa et al., 2017). Differences in dry mass partitioning as well as changes in morphology and physiology in different organs explain why fertilization can affect 
plant drought tolerance in different direction, accordingly with the environmental factors (soil texture and moisture, nutrient availability, stress intensity and duration) and capacity of the plant to make morphological and physiological acclimations to stressful conditions.

\section{Gas Exchange, Chlorophyll Fluorescence and Photosynthetic Pigments}

Drought stress reduces photosynthetic rate, due to a decrease in leaf expansion and associated damage to photosynthetic machinery (Wahid and Rasul, 2005). Our findings revealed that $P_{\mathrm{n}}$ significantly decreased under drought stress, but the drop was higher in unfertilized than in fertilized plants. Stomatal closure is considered to be the main factor in decreasing photosynthesis under water deficit conditions (Anjum et al., 2011). Stomatal closure in response to soil water deficit occurs because roots release high concentrations of abscisic acid (ABA) to the xylem and, as a result, the increased $\mathrm{pH}$ of xylem sap promotes ABA loading and subsequent transport to the shoots (Hartung et al., 2002). It is known that many drought-inducible genes respond to $\mathrm{ABA}$ level in leaves, for example, $\mathrm{ABA}$-dependent and $\mathrm{ABA}$-independent regulatory systems of gene expression can be regulated under drought stress (Zhu, 2002). Qin and Zeevart (2002) reported that protein dephosphorylation and farnesylation are responsible for ABA signaling, while Sauter et al. (2001) showed that ABA stimulates $\mathrm{K}+$ ions efflux from the guard cells, resulting in loss of turgor pressure, and decrease $G_{s}$. Reduction of $G_{\mathrm{s}}$ limits gas exchange, decreases $C_{\mathrm{i}}$ concentration and rates of photosynthesis, due to decline in Rubisco activity (Reddy et al., 2004). Similarly, our results indicated a significant decline in $G_{\mathrm{s}}$ and $C_{\mathrm{i}}$ under drought stress, more sharply in unfertilized than in fertilized plants. There is still debate, however, about whether drought restricts photosynthetic rate through stomatal closure or metabolic impairment (Tezara et al., 1999). Our results revealed that lower $P_{\mathrm{n}}$ was not only associated with $G_{\mathrm{s}}$ limitation, but was also due to impaired photosynthetic apparatus as reflected by significant decrease in $F_{\mathrm{v}} / F_{\mathrm{m}}$ during water deficit conditions. We also found that $\mathrm{P}$ application under drought stress conditions resulted in significantly higher $P_{\mathrm{n}}$ and $F_{\mathrm{V}} / F_{\mathrm{m}}$, but had no significant effect on stomatal conductance or transpiration rate. Thus, our results suggest an enhanced drought tolerance mechanism that conserves water, as indicated by increased LRWC, is stimulated by the addition of P. These results are consistent with previous studies that have reported enhanced photosynthetic activity in different plant species treated with P fertilizer under drought stress (Burman et al., 2009; Singh et al., 2013; Liu et al., 2015). In addition, other factors may have positive impacts on $P_{\mathrm{n}}$, in response to $\mathrm{P}$ application, such as increased production of assimilatory products (ATP and NADPH) and carboxylation activities (Lawlor and Cornic, 2002). WUE $\mathrm{Wntr}_{\text {in }}$ is considered to be an important component of adaptation to drought stress and in our study; WUE intr showed an opposite trend to $P_{\mathrm{n}}$, where it was significantly higher in droughtstressed plants, irrespective of $\mathrm{P}$ application. Therefore, plants under drought partially closed the stomata to reduce waters losses but the photosynthesis was affected proportionally in lesser extent. However, P application in our study had no significant effect on WUE $\mathrm{W}_{\text {intr }}$ of water-stressed and well-watered plants, as has also been reported in other studies (Oliveira et al., 2014; Liu et al., 2015).

Reduction in chlorophyll concentration is a sign of oxidative stress or pigment photooxidation under drought stress (Zhang and Kirkham, 1996) and low levels of photosynthetic pigments limit the rate of photosynthesis, thus reducing primary production. Our results showed that water deficit caused significant damage to the photosystem by degrading chloroplast pigments. The degraded chloroplast pigments may have also contributed to the decreased $P_{\mathrm{n}}$ observed in our study. Similar findings have been observed in other studies that suggest drought stress damage photosynthetic pigments (Frosi et al., 2013; Rivas et al., 2013). Previous work has shown that Chl $a$ and $\mathrm{Chl} b$ are susceptible to soil water deficiency (Farooq et al., 2009) Furthermore, soil dehydration has been shown to damage lamellae vesiculation and chloroplast membranes, inducing reductions in chlorophyll (Anjum et al., 2011). In our study, $\mathrm{P}$ application had a significant positive effect on Chl $a$ and Chl $b$ concentration, which may explain the higher $P_{\mathrm{n}}$ rate in $\mathrm{P}$ fertilized, drought-stressed plants, because high leaf chlorophyll concentration may allow for increased harvesting of light over shorter periods of time, as evidenced by the observed higher photosynthetic rates. Although there were changes in chlorophyll concentration, $\mathrm{P}$ fertilization did not change carotenoids concentration. This result is different of that found in the herbaceous Petunia hybrid, in which high P inhibited carotenoids biosynthetic genes (Nouri et al., 2015). Although our results were contradictory to some studies, in which negligible changes in chlorophyll concentrations due to P fertilization may be due to the duration and severity of drought (Zhang and Kirkham, 1996; Campbell and Sage, 2006; Singh et al., 2013). Nevertheless, our findings are supported by previous studies that suggest $\mathrm{P}$ application increases synthesis of photosynthetic pigments in plants under drought stress (Sharma, 1995; Sinha et al., 1995).

\section{Osmolytes Accumulation and Nitrogenous Compounds}

Plants adapt to drought environments by increasing the solute concentration of cells to maintain osmotic function and hydration (Ramanjulu and Bartels, 2002). Plants accumulate a variety of osmolytes in the cytosol, therefore the ability to increase osmotic pressure is considered to be a potential cellular drought tolerance mechanism, as it improves or maintains turgidity and continuation of plant growth. Apart from osmotic adjustment, osmolytes also help in ROS detoxification, membrane stabilization, as well as protecting macromolecules (Keunen et al., 2013). Our results showed that there was no significant increase in SS concentration under drought in unfertilized plants. However, $\mathrm{P}$ fertilization significantly increased SS concentration in drought-stressed plants compared with well-watered; this may be due to the inhibition of normal SS utilization and translocation during water stress or hydrolysis of starch (Shubhra et al., 2004). Accumulation of SS protects 
cells in water deficit environments by substituting the hydroxyl group for water, thus maintaining a hydrophilic interaction between proteins and membranes to retain membrane integrity (Hoekstra et al., 2001). This positive effect of $\mathrm{P}$ fertilization on SS accumulation and mobilization clearly indicates its role in improving drought tolerance of $P$. zhennan. We found that proline concentration was significantly higher in droughtstressed plants than in well-watered. Proline accumulation in low moisture environments is due to reciprocal regulation of two pathways: up-regulation of proline synthesizing enzymes and down-regulation of proline degrading enzymes activities (Peng et al., 1996). Reddy et al. (2004) reported that the accumulation of proline in response to drought stress was regulated by a rate limiting enzyme, PFC5, in higher plants. Previous studies conducted on different plant species showed varied response of proline accumulation to $\mathrm{P}$ application under drought stress. For example Liu et al. (2015) suggested that P application significantly decrease proline concentration in water-stressed Fargesia rufa; however, Al-Karaki et al. (1996) found that P application significantly increased proline accumulation in sorghum while the bean plants showed higher accumulation at low P level than at high $\mathrm{P}$ level. We found that $\mathrm{P}$ application neither decreased nor enhanced proline accumulation in drought-stressed plants. It clearly indicates that proline accumulation responses to $\mathrm{P}$ fertilization in drought-stressed plants are inconsistent, varying according to specific tolerance mechanisms and level of $\mathrm{P}$ applied. It is already understood that proline accumulation increase under drought stress in many plant species but not necessarily with $\mathrm{P}$ application.

Nitrogen is an important nutrient for plant growth as it is involved in the synthesis of chlorophyll, amino acids, nucleic acid, and proteins. Generally, water stress can reduce available N uptake, resulting in a decrease in the production of nitrogenous compounds (Lawlor and Cornic, 2002; Garg et al., 2004). Similarly, our results showed lower amounts of $\mathrm{NH}_{4}{ }^{+}, \mathrm{NO}_{3}{ }^{-}$, and SP under limited water supply, regardless of $\mathrm{P}$ fertilization. Possible reasons for this decreased SP concentration in droughtstressed plants include an associated increased function of protease enzymes, proteolysis or decreased protein synthesis, as well as the lower $P_{\mathrm{n}}$, i.e., less carbon to build any metabolite. Furthermore, our findings revealed that $\mathrm{P}$ application slightly up-regulated $\mathrm{NH}_{4}{ }^{+}$and $\mathrm{NO}_{3}{ }^{-}$levels in water-stressed plants and these may be attributed to changes in associated enzyme activities (Burman et al., 2004, 2009). Azcon et al. (1996) also observed a positive effect of $\mathrm{P}$ fertilization on the reduction and assimilation of nitrogenous compounds. It appears that $\mathrm{P}$ fertilization can enhance the drought tolerance of $P$. zhennan by accumulating osmoprotectors and enhancing nitrogenous compounds reduction and assimilation.

\section{ROS Production, Lipid Peroxidation, and Antioxidant System}

Response to drought is an inherent property of a plant, but it also depends on the length and severity of stress period. Long term drought stress causes a decline in the rate of photosynthesis, leading to an over-production of ROS (Foyer and
Noctor, 2005; Carvalho, 2008). An increase in ROS level triggers protein degradation, lipid peroxidation, DNA fragmentation and may cause cell death (Apel and Hirt, 2004). ROS $\left(\mathrm{O}_{2}{ }^{--}\right.$ and $\mathrm{H}_{2} \mathrm{O}_{2}$ ) production and MDA content were found to be significantly higher in drought-stressed plants compared with the well-watered, regardless of $\mathrm{P}$ application because of low photosynthetic rate and other physiological disruption within the cell. Induction of antioxidant enzyme activities is a general tolerance strategy to drought stress, as it helps plants to overcome oxidative stress and associated damage. The antioxidative enzyme SOD is responsible to dismutase $\mathrm{O}_{2}{ }^{-}$ into $\mathrm{H}_{2} \mathrm{O}_{2}$ in the chloroplast, mitochondrion, cytoplasm, and peroxisome, while POD and CAT play important functions in scavenging $\mathrm{H}_{2} \mathrm{O}_{2}$. Antioxidative (SOD, POD, and CAT) enzyme activities were also found to be significantly higher in drought-stressed plants compared with well-watered plants, irrespective of $\mathrm{P}$ application, suggesting a strong antioxidant defense mechanism in $P$. zhennan under drought conditions. These results indicate that antioxidative enzyme processing is substrate (ROS) inducible, leading to increased expression of genes encoding these enzymes. Reddy et al. (2004) reported that drought stress induced mRNAs corresponded to the genes of antioxidant enzymes. Similar results were also reported in other studies conducted on variety of plant species (Mittler, 2002; Murshed et al., 2013; Oliveira et al., 2014). In our study, P application resulted in slightly lower levels of $\mathrm{O}_{2}{ }^{--}$and $\mathrm{H}_{2} \mathrm{O}_{2}$ under drought stress, while level of MDA was significantly lower. $\mathrm{P}$ application had no significant effect on antioxidant enzymes or their activities and remained higher under drought treatment. Our findings indicate $P$. zhennan has the potential to tolerate natural drought conditions and that $\mathrm{P}$ fertilization may have a positive role in maintaining the tolerance capacity and mitigating the effects of drought stress.

\section{CONCLUSION}

Drought stress severely affected the growth and metabolism of $P$. zhennan. However, our findings also revealed that this tree species utilizes a range of drought tolerant strategies. These strategies include decreased leaf area, limited stomatal conductance and transpiration rate, increased antioxidative activities and accumulation of osmoprotectors. $\mathrm{P}$ application had negligible or almost no effect on the morphological and physio-biochemical traits under well-watered conditions. However, P application had significant positive effects on the root biomass, net photosynthesis rate, chlorophyll fluorescence, leaf relative water content, and chloroplast pigment as well as in biochemical adjustments (i.e., SS) that confer improved tolerance of $P$. zhennan to drought stress. These findings provide baseline information to improve our understanding of the morphological and physio-biochemical responses of $P$. zhennan under drought stress and the positive effects of $\mathrm{P}$ fertilization on plants in drought-stressed environments. Balanced $\mathrm{P}$ fertilization may facilitate $P$. zhennan seedlings in agroforestry system if there are frequent drought events because $\mathrm{P}$ has positive effect on drought tolerance. We suggest further studies into underlying 
biochemical and molecular mechanisms under drought stress conditions, as well as and the possible role of different levels of $\mathrm{P}$ fertilization in mitigating negative effects of drought or for improving drought tolerance of P. zhennan.

\section{AUTHOR CONTRIBUTIONS}

$\mathrm{KP}$ and AT designed the study including experimental design. AT, ZL, OO, WC, and AZ carried out the physiological studies. AT analyzed the data and drafted the manuscript. CG, FS, ZL, OO, and CL helped in analyzing data, while KP, CG, XS, LZ,

\section{REFERENCES}

Al-Karaki, G. N., Clark, R. B., and Sullivan, C. Y. (1996). Phosphorous nutrition and water stress effects on proline accumulation in sorghum and bean. J. Plant Physiol. 148, 745-751. doi: 10.1016/S0176-1617(96)80378-6

Anjum, S. A., Xie, X., Wang, L., Saleem, M. F., Man, C., and Lei, W. (2011). Morphological, physiological and biochemical responses of plants to drought stress. Afr. J. Agric. Res. 6, 2026-2032.

Apel, K., and Hirt, H. (2004). Reactive oxygen species: metabolism, oxidative stress, and signal transduction. Annu. Rev. Plant Biol. 55, 373-399. doi: 10.1146/ annurev.arplant.55.031903.141701

Azcon, R., Gomez, M., and Tobar, R. (1996). Physiological and nutritional responses by Lactuca sativa L. to nitrogen sources and mychorrhizal fungi under drought condition. Biol. Fertil. Soils 22, 156-161. doi: 10.1007/ BF00384448

Bartlett, M. K., Scoffoni, C., and Sack, L. (2012). The determinants of leaf turgor loss point and prediction of drought tolerance of species and biomes: a global meta-analysis. Ecol. Lett. 15, 393-405. doi: 10.1111/j.1461-0248.2012.01751.x

Bohnert, H. J., and Jensen, R. G. (1996). Strategies for engineering water-stress tolerance in plants. Trends Biotechnol. 14, 89-97. doi: 10.1016/0167-7799(96) 80929-2

Bohnert, H. J., and Sheveleva, E. (1998). Plant stress adaptations-making metabolism move. Curr. Opin. Plant Biol. 1, 267-274. doi: 10.1016/S13695266(98)80115-5

Burman, U., Garg, B. K., and Kathju, S. (2004). Interactive effects of thiourea and phosphorus on cluster bean under water stress. Biol. Plant 48, 61-65. doi: 10.1023/B:BIOP.0000024276.03834.8d

Burman, U., Garg, B. K., and Kathju, S. (2009). Effect of phosphorus application on cluster bean under different intensities of water stress. J. Plant Nutr. 32, 668-680. doi: 10.1080/01904160802715620

Campbell, C. D., and Sage, R. F. (2006). Interactions between the effects of atmospheric CO2 content and $\mathrm{P}$ nutrition on photosynthesis in white lupin (Lupinus albus L.). Plant Cell. Environ. 29, 844-853. doi: 10.1111/j.1365-3040. 2005.01464.x

Carvalho, M. H. C. D. (2008). Drought stress and reactive oxygen species. Plant Signal. Behav. 3, 156-165. doi: 10.4161/psb.3.3.5536

Centritto, M., Maguani, F., Lee, H. S. J., and Jarvis, P. G. (1999). Interactive effects of elevated CO2 and drought on cherry (Prunus avium) seedlings. II. Photosynthetic capacity and water relations. New Phytol. 141, 141-153. doi: 10.1046/j.1469-8137.1999.00327.x

Chapin, S. F. (1980). The mineral nutrition of wild plants. Ann. Rev. Ecol. Syst. 11, 233-260. doi: 10.1146/annurev.es.11.110180.001313

Cortina, J., Vilagrosa, A., and Trubat, R. (2013). The role of nutrients for improving seedling quality in drylands. New For. 44, 719-732. doi: 10.1007/s11056-0139379-3

Costa, L., Faustino, L. I., and Graciano, C. (2017). The spatial distribution of phosphate in the root system modulates $\mathrm{N}$ metabolism and growth in Eucalyptus grandis young plants. Trees 31, 247-257. doi: 10.1007/s00468-0161480-8

Cramer, M. D., Hawkins, H. J., and Verboom, G. A. (2009). The importance of nutritional regulation of plant water flux. Oecologia 161, 15-24. doi: 10.1007/ s00442-009-1364-3 and CL contributed to revising the draft. DS, DM, QX, and XW contributed reagents, materials, and analysis tools.

\section{FUNDING}

This study was supported by the Ministry of Sciences and Technology of China (Grant Nos. 2016YFC0502101 and 2015BAD07B050304), and by the National Natural Science Foundation of China (Grant Nos. 31370632 and 31500517). The research was sponsored by CAS-TWAS President's Fellowship for international Ph.D. students.

Demirevska, K., Zasheva, D., Dimitrov, R., Simova-Stoilova, L., Stamenova, M., and Feller, U. (2009). Drought stress effects on Rubisco in wheat: changes in the Rubisco large subunit. Acta Physiol. Plant. 31, 1129-1138. doi: 10.1007/s11738009-0331-2

Doerner, P. (2008). Phosphate starvation signaling: a threesome controls systemic P(i) homeostasis. Curr. Opin. Plant Biol. 11, 536-540. doi: 10.1016/j.pbi.2008. 05.006

dos Santos, M. G., Ribeiro, R. V., de Oliveira, R. F., Machado, E. C., and Pimentel, C. (2006). The role of inorganic phosphate on photosynthesis recovery of common bean after a mild water deficit. Plant Sci. 170, 659-664. doi: 10.1016/j.plantsci. 2005.10.020

dos Santos, M. G., Ribeiro, R. V., Oliveira, R. F., and Pimentel, C. (2004). Gas exchange and yield response to foliar phosphorus application in Phaseolus vulgaris L. under drought. Braz. J. Plant Physiol. 16, 171-179. doi: 10.1590/ S1677-04202004000300007

Elstner, E. F., and Heupel, A. (1976). Formation of hydrogen peroxide by isolated cell walls from horseradish (Armoracia lapathifolia Gilib.). Planta 130, 175-180. doi: 10.1007/BF00384416

Farooq, M., Wahid, A., Kobayashi, N., Fujita, D., and Basra, S. M. A. (2009). Plant drought stress: effects, mechanisms and management. Agron. Sustain. Dev. 29, 185-212. doi: 10.1051/agro:2008021

Faustino, L. I., Bulfe, N. M. L., Pinazo, M. A., Monteoliva, S. E., and Graciano, C. (2013). Dry weight partitioning and hydraulic traits in young Pinus taeda trees fertilized with nitrogen and phosphorus in a subtropical area. Tree Physiol. 33, 241-251. doi: 10.1093/treephys/tps129

Fleisher, D. H., Wang, Q., Timlin, D. J., Chun, J. A., and Reddy, V. R. (2012). Response of potato gas exchange and productivity to phosphorus deficiency and carbon dioxide enrichment. Crop. Sci. 52, 1803-1815. doi: 10.2135/cropsci2011. 09.0526

Foyer, C. H., and Noctor, G. (2005). Redox homeostasis and antioxidant signalling: a metabolic interface between stress perception and physiological responses. Plant Cell 17, 1866-1875. doi: 10.1105/tpc.105.033589

Frosi, G., Oliveira, M. T., Almeida-Cortez, J. S., and dos Santos, M. G. (2013). Ecophysiological performance of Calotropis procera: an exotic and evergreen species in Caatinga, Brazilian semi-arid. Acta Physiol. Plant 35, 335-344.

$\mathrm{Fu}, \mathrm{J}$., and Huang, B. (2001). Involvement of antioxidants and lipid peroxidation in the adaptation of two cool-season grasses to localized drought stress. Environ. Exp. Bot. 45, 105-114. doi: 10.1016/S0098-8472(00)00084-8

Gao, J., Zhang, W., Li, J., Long, H., He, W., and Li, X. (2016). Amplified fragment length polymorphism analysis of the population structure and genetic diversity of Phoebe zhennan (Lauraceae), a native species to China. Biochem. Syst. Ecol. 64, 149-155. doi: 10.1016/j.bse.2015.11.001

Garg, B. K., Burman, U., and Kathju, S. (2004). The influence of phosphorus nutrition on the physiological response of moth bean genotypes to drought. J. Plant Nutr. Soil Sci. 167, 503-508. doi: 10.1002/jpln.200320368

Graciano, C., Faustino, L. I., and Zwieniecki, M. A. (2016). Hydraulic properties of Eucalyptus grandis in response to nitrate and phosphate deficiency and sudden changes in their availability. J. Plant Nutr. Soil Sci. 179, 303-309. doi: 10.1002/jpln.201500207

Graciano, C., Guiamet, J. J., and Goya, J. F. (2005). Impact of nitrogen and phosphorus fertilization on drought responses in Eucalyptus grandis seedlings. For. Ecol. Manag. 212, 40-49. doi: 10.1016/j.foreco.2005.02.057 
Grant, C., Bittman, S., Montreal, M., Plenchette, C., and Morel, C. (2005). Soil and fertilizer phosphorus: Effects on plant P supply and mycorrhizal development. Can. J. Plant Sci. 85, 3-14. doi: 10.4141/P03-182

Guo, B., Jin, Y., Wussler, C., Blancaflor, E., Motes, C., and Versaw, W. (2008). Functional analysis of the Arabidopsis PHT4 family of intracellular phosphate transporters. New Phytol. 177, 889-898. doi: 10.1111/j.1469-8137.2007.02331.x

Harfouche, A., Meilan, R., and Altman, A. (2014). Molecular and physiological responses to abiotic stress in forest trees and their relevance to tree improvement. Tree Physiol. 34, 1181-1198. doi: 10.1093/treephys/tpu012

Hartung, W., Sauter, A., and Hose, E. (2002). Abscisic acid in the xylem: where does it come from, where does it go to? J. Exp. Bot. 53, 27-37. doi: 10.1093/jexbot/53. 366.27

He, M., and Dijkstra, F. A. (2014). Drought effect on plant nitrogen and phosphorus: a Meta-analysis. New Phytol. 204, 924-931. doi: 10.1111/nph. 12952

Hoekstra, F. A., Golovina, E. A., and Buitink, J. (2001). Mechanisms of plant desiccation tolerance. Trends Plant Sci. 6, 431-438. doi: 10.1016/S13601385(01)02052-0

$\mathrm{Hu}$, Y., and Schmidhalter, U. (2001). Effects of salinity and macronutrient levels on micronutrients in wheat. J. Plant Nutr. 24, 273-281. doi: 10.1081/PLN100001387

Hu, Y., Wang, B., Hu, T., Chen, H., Li, H., Zhang, W., et al. (2015). Combined action of an antioxidant defence system and osmolytes on drought tolerance and post-drought recovery of Phoebe zhennan S. Lee saplings. Acta Physiol. Plant. 37, 84. doi: 10.1007/s11738-015-1831-x

Jin, J., Lauricella, D., Armstrong, R., Sale, P., and Tang, C. (2015). Phosphorus application and elevated $\mathrm{CO} 2$ enhance drought tolerance in field pea grown in a phosphorus-deficient vertisol. Ann. Bot. 116, 975-985. doi: 10.1093/aob/ mcu209

Jones, C. A., Jacobsen, J. S., and Wraithl, J. M. (2005). Response of malt barley to phosphorus fertilization under drought conditions. J. Plant Nutr. 28, 1605-1617. doi: 10.1080/01904160500203531

Keunen, E., Peshev, D., Vangronsveld, J., Ende, W. V. D., and Cuypers, A. (2013). Plant sugars are crucial players in the oxidative challenge during abiotic stress: extending the traditional concept. Plant Cell Environ. 36, 1242-1255. doi: $10.1111 /$ pce. 12061

Lawlor, D. W., and Cornic, G. (2002). Photosynthetic carbon assimilation and associated metabolism in relation to water deficits in higher plants. Plant Cell Environ. 25, 275-294. doi: 10.1046/j.0016-8025.2001.00814.x

Ledger, M. E., Brown, L. E., Edwards, F. K., Milner, A. M., and Woodward, G. (2013). Drought alters the structure and functioning of complex food webs. Nat. Clim. Change 3, 223-227. doi: 10.1038/nclimate1684

Li, T., Sun, Y., Ruan, Y., Xu, L., Hu, Y., Hao, Z., et al. (2016). Potential role of D-myo-inositol-3-phosphate synthase and 14-3-3 genes in the crosstalk between Zea mays and Rhizophagus intraradices under drought stress. Mycorrhiza 26, 879-893. doi: 10.1007/s00572-016-0723-2

Liao, H., and Yan, X. (2000). Adaptive changes and genotypic variation for root architecture of common bean in response to phosphorus deficiency. Acta Bot. Sin. 42, 158-163.

Lichtenthaler, H. K., and Buschmann, C. (2001). "Chlorophylls and carotenoids: measurement and characterization by UV-VIS spectroscopy," in Current Protocols in Food Analytical Chemistry (CPFA), eds R. E. Wrolstad, T. E. Acree, H. An, E. A. Decker, M. H. Penner, D. S. Reid, et al. (New York, NY: John Wiley and Sons), F4.3.1-F4.3.8. doi: 10.1002/0471142913.faf0403s01

Lin, S. I., Chiang, S. F., Lin, W. Y., Chen, J. W., Tseng, C. Y., Wu, P. C., et al. (2008). Regulatory network of microRNA399 and PHO2 by systemic signaling. Plant Physiol. 147, 732-746. doi: 10.1104/pp.108.116269

Liu, C. G., Wang, Y. J., Pan, K. W., Jin, Y. Q., Li, W., and Zhang, L. (2015). Effects of phosphorus application on photosynthetic carbon and nitrogen metabolism, water use efficiency and growth of dwarf bamboo (Fargesia rufa) subjected to water deficit. Plant Physiol. Biochem. 96, 20-28. doi: 10.1016/j.plaphy.2015. 07.018

Liu, C. G., Wang, Y. J., Pan, K. W., Zhu, T. T., Li, W., and Zhang, L. (2014). Carbon and nitrogen metabolism in leaves and roots of dwarf bamboo (Fargesia denudata Yi) subjected to drought for two consecutive years during sprouting period. J. Plant Growth Regul. 33, 243-255. doi: 10.1007/s00344-013-9367-z

López-Arredondo, D. L., Leyva-González, M. A., González-Morales, S. I., LópezBucio, J., and Herrera-Estrella, L. (2014). Phosphate nutrition: improving low phosphate tolerance in crops. Annu. Rev. Plant Biol. 65, 95-123. doi: 10.1146/annurev-arplant-050213-035949

Mahajan, S., and Tuteja, N. (2005). Cold, salinity and drought stresses: an overview. Arch. Biochem. Biophys. 444, 139-158. doi: 10.1016/j.abb.2005.10.018

Meng, L. S., and Yao, S. Q. (2015). Transcription co-activator Arabidopsis ANGUSTIFOLIA3 (AN3) regulates water-use efficiency and drought tolerance by modulating stomatal density and improving root architecture by the transrepression of YODA (YDA). Plant Biotechnol. J. 13, 893-902. doi: 10.1111/ pbi. 12324

Mitchell, J. (1957). A review of tracer studies in Saskatchewan on the utilization of phosphates by grain crops. J. Soil Sci. 8, 73-85. doi: 10.1111/j.1365-2389.1957. tb01869.x

Mittler, R. (2002). Oxidative stress, antioxidants and stress tolerance. Trends Plant Sci. 7, 405-410. doi: 10.1016/S1360-1385(02)02312-9

Murphy, J., and Riley, J. P. (1962). A modified single solution method for the determination of phosphate in natural waters. Anal. Chim. Acta 27, 31-36. doi: 10.1016/S0003-2670(00)88444-5

Murshed, R., Lopez-Lauri, F., and Sallanon, H. (2013). Effect of water stress on antioxidant systems and oxidative parameters in fruits of tomato (Solanum lycopersicon L, cv. Micro-tom). Physiol. Mol. Biol. Plants 19, 363-378. doi: 10.1007/s12298-013-0173-7

Naeem, M., and Khan, M. M. A. (2009). Phosphorus ameliorates crop productivity, photosynthesis, nitrate reductase activity and nutrient accumulation in coffee senna (Senna occidentalis L.) under phosphorus-deficient soil. J. Plant Interact. 4, 145-153. doi: 10.1080/17429140802193178

Neale, D. B., and Kremer, A. (2011). Forest tree genomics: growing resources and applications. Nat. Rev. Genet. 12, 111-122. doi: 10.1038/nrg2931

Nouri, E., Breuillin-Sessoms, F., Feller, U., and Reinhardt, D. (2015). Phosphorus and nitrogen regulate arbuscular mycorrhizal symbiosis in Petunia hybrida. PLOS ONE 10:e0127472. doi: 10.1371/journal.pone.0127472

Oliveira, M. T., Medeiros, C. D., Frosi, G., and dos Santos, M. G. (2014). Different mechanisms drive the performance of native and invasive woody species in response to leaf phosphorus supply during periods of drought stress and recovery. Plant Physiol. Biochem. 82, 66-75. doi: 10.1016/j.plaphy.2014.05.006

Olsen, S. R., and Sommers, L. E. (1982). "Phosphorus," in Methods of Soil Analysis, Part 2, eds A. L. Page, R. H. Miller, and D. R. Keeney (Madison, WI: American Society of Agronomy), 403-430.

Patterson, B. D., MacRae, E. A., and Ferguson, I. B. (1984). Estimation of hydrogen peroxide in plant extracts using titanium (IV). Anal. Biochem. 139, 487-492. doi: 10.1016/0003-2697(84)90039-3

Peng, Z., Lu, Q., and Verma, D. P. S. (1996). Reciprocal regulation of D1pyrroline-5- carboxylate synthetase and proline dehydrogenase genes control levels during and after osmotic stress in plants. Mol. Gen. Genet. 253, 334-341.

Qin, X., and Zeevart, Q. J. (2002). Overexpression of a 9-cis-epoxycarotenoid dioxygenase gene in Nicotiana plumbaginifolia increases abscisic acid and phaseic acid levels and enhances drought tolerance. Plant Physiol. 128, 544-551. doi: 10.1104/pp.010663

Ram, D., Ram, M., and Singh, R. (2006). Optimization of water and nitrogen application to menthol mint (Mentha arvensis L.) through sugarcane trash mulch in a sandy loam soil of semi-arid subtropical climate. Bioresour. Technol. 97, 886-893. doi: 10.1016/j.biortech.2005.04.047

Ramanjulu, S., and Bartels, D. (2002). Drought- and desiccation-induced modulation of gene expression in plants. Plant Cell Environ. 25, 141-151. doi: 10.1046/j.0016-8025.2001.00764.x

Razaq, M., Zhang, P., Shen, H.-L., and Salahuddin. (2017). Influence of nitrogen and phosphorous on the growth and root morphology of Acer mono. PLOS ONE 12:e0171321. doi: 10.1371/journal.pone.0171321

Reddy, A. R., Chaitanya, K. V., and Vivekanandan, M. (2004). Drought-induced responses of photosynthesis and antioxidant metabolism in higher plants. J. Plant Physiol. 161, 1189-1202. doi: 10.1016/j.jplph.2004.01.013

Ren, P., Ma, X., Li, B., Meng, Y., Lai, Y., Si, E., et al. (2016). Identification and selection of low-phosphate-tolerant germplasm in barley (Hordeum vulgare L.). Soil Sci. Plant Nutr. 62, 471-480. doi: 10.1080/00380768.2016.1223521

Rivas, R., Oliveira, M. T., and dos Santos, M. G. (2013). Three cycles of water deficit from seed to young plants of Moringa oleifera woody species improves stress tolerance. Plant Physiol. Biochem. 63, 200-208. doi: 10.1016/j.plaphy.2012. 11.026 
Rostamza, M., Chaichi, M. R., Jahansooz, M. R., Rahimian Mashhadi, H., and Sharifi, H. R. (2011). Effects of water stress and nitrogen fertilizer on multi-cut pearl millet forage yield, nitrogen, and water use efficiency. Commun. Soil Sci. Plant Anal. 42, 2427-2440. doi: 10.1080/00103624.2011.609252

Rouached, H., Arpat, A. B., and Poirier, Y. (2010). Regulation of phosphate starvation responses in plants: signaling players and cross-talks. Mol. Plant 3, 288-299. doi: $10.1093 / \mathrm{mp} / \mathrm{ssp} 120$

Sample, E. C., Soper, R. J., and Racz, G. J. (1980). "Reaction of phosphate fertilizers in soils," in The Role of Phosphorus in Agriculture, eds F. E. Khasawneh, E. C. Sample, and E. J. Kamprath (Madison, WI: ASA), 262-310.

Sanaullah, M., Rumpel, C., Charrier, X., and Chabbi, A. (2012). How does drought stress influence the decomposition of plant litter with contrasting quality in a grassland ecosystem? Plant Soil 352, 277-288. doi: 10.1007/s11104-011-0995-4

Sardans, J., and Penuelas, J. (2012). The role of plants in the effects of global change on nutrient availability and stoichiometry in the plant-soil system. Plant Physiol. 160, 1741-1761. doi: 10.1104/pp.112.208785

Sato, A. M., Catuchi, T. A., Ribeiro, R. V., and Souza, G. M. (2010). The use of network analysis to uncover homeostatic responses of a drought-tolerant sugarcane cultivar under severe water deficit and phosphorus supply. Acta Physiol. Plant 32, 1145-1151. doi: 10.1007/s11738-010-0506-x

Sauter, A., Davies, W. J., and Hartung, W. (2001). The long distance abscisic acid signal in the droughted plant: the fate of the hormone on its way from root to shoot. J. Exp. Bot. 52, 1991-1997. doi: 10.1093/jexbot/52.363.1991

Schachtman, D. P., Reid, R. J., and Ayling, S. M. (1998). Phosphorus uptake by plants: from soil to cell. Plant Physiol. 116, 447-453. doi: 10.1104/pp.116.2.447

Schimel, J., Balser, T. C., and Wallenstein, M. (2007). Microbial stress-response physiology and its implications for ecosystem function. Ecology 88, 1386-1394. doi: 10.1890/06-0219

Schunmann, P. H. D., Richardson, A. E., Smith, F. W., and Delhaize, E. (2004). Characterization of promoter expression patterns derived from the Pht phosphate transporter genes of barley (Hordeum vulgare L.). J. Exp. Bot. 55, 855-865. doi: 10.1093/jxb/erh103

Sharma, P. N. (1995). Water relations and photosynthesis in phosphorous deficient mulberry plants. Indian J. Plant Physiol. 38, 298-300.

Shubhra, Dayal, J., Goswami, C. L., and Munjal, R. (2004). Influence of phosphorus application on water relations, biochemical parameters and gum content in cluster bean under water deficit. Biol. Plant 48, 445-448. doi: 10.1023/B:BIOP. 0000041101.87065.c9

Singh, S. K., Badgujar, G., Reddy, V. R., Fleisher, D. H., and Bunce, J. A. (2013). Carbon dioxide diffusion across stomata and mesophyll and photo-biochemical processes as affected by growth $\mathrm{CO} 2$ and phosphorus nutrition in cotton. J. Plant Physiol. 170, 801-813. doi: 10.1016/j.jplph.2013.01.001

Singh, V., Pallaghy, C. K., and Singh, D. (2006). Phosphorus nutrition and tolerance of cotton to water stress: I. Seed cotton yield and leaf morphology. Field Crop Res. 96, 191-198. doi: 10.1016/j.fcr.2005.06.009

Sinha, R. B., Sakal, R., and Kumar, S. (1995). Sulphur and phosphorous nutrition of winter maize in calcareous soil. J. Indian Soc. Soil Sci. 43, 413-441.

Suriyagoda, L. D. B., Ryan, M. H., Renton, M., and Lambers, H. (2011). Aboveand belowground interactions of grass and pasture legume species when grown together under drought and low phosphorus availability. Plant Soil 348, 281-297. doi: 10.1007/s11104-011-0754-6

Tang, Z. C. (1999). The Experimental Guide of Modern Plant Physiology. Shanghai: Science Press, 138-139, 154-157.

Tardieu, F. (2012). Any trait or trait-related allele can confer drought tolerance: just design the right drought scenario. J. Exp. Bot. 63, 25-31. doi: 10.1093/jxb/ err269

Tezara, W., Mitchell, V. J., Driscoll, S. D., and Lawlor, D. W. (1999). Water stress inhibits plant photosynthesis by decreasing coupling factor and ATP. Nature 401, 914-917. doi: 10.1038/44842

Versaw, W., and Harrison, M. (2002). A chloroplast phosphate transporter, PHT2;1, influences allocation of phosphate within the plant and phosphatestarvation responses. Plant Cell 14, 1751-1766. doi: 10.1105/tpc.002220

Wahid, A., and Rasul, E. (2005). "Photosynthesis in leaf, stem, flower and fruit," in Handbook of Photosynthesis, 2nd Edn, ed. M. Pessarakli (Boca Raton, FL: CRC Press), 479-497.

Wu, W. M. (2009). Study on stand structure and growth law of near mature Phoebe bournei plantation. China For. Sci. Technol. 23, 75-78.

Xu, Z. Z., Zhou, G. S., and Shimizu, H. (2009). Are plant growth and photosynthesis limited by pre-drought following rewatering in grass? J. Exp. Bot. 60, 3737-3749. doi: 10.1093/jxb/erp216

Yang, F., and Miao, L. F. (2010). Adaptive responses to progressive drought stress in two poplar species originating from different altitudes. Silva Fenn. 44, 23-37. doi: 10.1111/j.1399-3054.2010.01375.x

Yin, C. Y., Pang, X. Y., Chen, K., Gong, R. G., Xu, G., and Wang, X. (2012). The water adaptability of Jatropha curcas is modulated by soil nitrogen availability. Biomass Bioenergy 47, 71-81. doi: 10.1016/j.biombioe.2012.09.062

Zhang, J., and Kirkham, M. B. (1996). Antioxidant response to drought in sunflower and sorghum seedlings. New Phytol. 132, 361-373. doi: 10.1111/j. 1469-8137.1996.tb01856.x

Zhang, Z. L., and Qu, W. J. (2003). The Experimental Guidance of Plant Physiology. Beijing: Higher Education Press, 127-137.

Zhou, Y., Lam, H. M., and Zhang, J. (2007). Inhibition of photosynthesis and energy dissipation induced by water and high light stresses in rice. J. Exp. Bot. 58, 1207-1217. doi: 10.1093/jxb/erl291

Zhu, J. K. (2002). Salt and drought stress signal transduction in plants. Annu. Rev. Plant Biol. 53, 247-273. doi: 10.1146/annurev.arplant.53.091401.143329

Conflict of Interest Statement: The authors declare that the research was conducted in the absence of any commercial or financial relationships that could be construed as a potential conflict of interest.

Copyright (c) 2017 Tariq, Pan, Olatunji, Graciano, Li, Sun, Sun, Song, Chen, Zhang, $W u$, Zhang, Mingrui, Xiong and Liu. This is an open-access article distributed under the terms of the Creative Commons Attribution License (CC BY). The use, distribution or reproduction in other forums is permitted, provided the original author(s) or licensor are credited and that the original publication in this journal is cited, in accordance with accepted academic practice. No use, distribution or reproduction is permitted which does not comply with these terms. 